\title{
LIMITATIONS AND OPPORTUNITIES FOR FUNDING AGRICULTURE AND RURAL DEVELOPMENT IN THE REPUBLIC OF SERBIA
}

\author{
Lela Ristićl, Violeta Todorović2, Milena Jakšićc \\ *Corresponding authorE-mail: lristic@kg.ac.rs
}

\begin{abstract}
A R T I C LE IN F O
A B S T R A C T

Review Article

Funding is one of the most important issues of agriculture

Received: 23 May 2018 and rural development of the Republic of Serbia, because

Accepted: 08 July 2018

doi:10.5937/ekoPolj1803123R

UDC 338.43:502.131(497.11) insufficient financial resources allocated to this sector of the country's economy are considered the key limitation for better valorization of agricultural resources and the revitalization of rural areas. Agribusiness and rural

Keywords:

agriculture, rural development, funding, Republic of Serbia

JEL: O13, Q18, G21, G28 development have a major socio-economic importance for the Republic of Serbia, which is supported by a number of strategic documents, development indicators and scientific and expert analysis implemented in the country and at a global level; therefore, the aim of this study is to determine whether it is necessary and possible to improve the funding of agricultural development and rural economy of the Republic of Serbia, in current conditions. The survey results indicate potential sources, i.e., the possible ways of funding agriculture and non-agricultural activities in the rural areas of the Republic of Serbia.
\end{abstract}

(C) 2018 EA. All rights reserved.

\section{Introduction}

Topics including production of safe foods in sufficient quantities and at reasonable prices, conservation and rational use of natural resources, economic and financial issues, as well as other questions related to the development of agricultural and rural economy, have been studied by numerous authors, institutions and organizations worldwide.

Agriculture is of great socio-economic importance for the Republic of Serbia, especially because of its share in GDP, exports and employment. The important characteristics

1 Lela Ristić, PhD, Associate Professor, University of Kragujevac - Faculty of Economics, Djure Pucara Starog 3, 34000 Kragujevac, Republic of Serbia, Phone: +381 034303552 , E-mail: lristic@kg.ac.rs, https://orcid.org/0000-0002-4590-8261

2 Violeta Todorović, PhD, Associate Professor, University of Kragujevac - Faculty of Economics, Djure Pucara Starog 3, 34000 Kragujevac, Republic of Serbia, Phone: +381 034303 585, E-mail: v.todorovic@kg.ac.rs, https://orcid.org/0000-0002-3258-160X

3 Milena Jakšić, PhD, Full Professor, University of Kragujevac - Faculty of Economics, Djure Pucara Starog 3, 34000 Kragujevac, Republic of Serbia, Phone: +381 034303557 , E-mail: milenaj@kg.ac.rs, https://orcid.org/0000-0003-0553-6085 
of agriculture and rural areas relates to the available natural resources, which are not properly utilized, due to a series of internal and external constraints in terms of their better valuation. Insufficient funding and lack of institutional support are among the most important factors that hinder the development of both agriculture and rural economy. Although great efforts have been made by the state and other relevant stakeholders, funding is still insufficient, regardless of the fact that the resource potential of rural areas is very highly estimated, as well as the natural conditions, country's long-lasting agricultural production tradition and the demand for agri-food products on the world market. Namely, very modest financial means that are invested in this sector of the economy have a very unfavorable effect on the situation in this sector and its prospects for further development.

The subject of this paper is funding of agriculture and rural development in the Republic of Serbia, while the aim of the research is to determine whether it is necessary and possible to improve the funding of the agriculture and rural economy development in Serbia.

The initial hypothesis is that if a larger number of quality funding sources for agriculture and rural development of the Republic of Serbia are provided, together with the adequate institutional support and in accordance with the specific characteristics of the domestic economic environment and complex international circumstances, it is possible to expect more successful business activities in this sector of the economy.

In terms of the research methodology, the following methods were used: descriptive research method, comparative analysis method, method of analysis and synthesis and SWOT analysis. In this respect, previous studies, relevant statistical publications and policy documents, and especially the legislation relating to the agricultural sector, rural development and funding, are of a paramount importance.

\section{Literature review}

Considering the global importance of agriculture and rural development, numerous studies have been carried out in order to research these scientific fields. Moseley (2003) points to the basic principles of rural development and role of agriculture in rural economy, as well as the practical importance of their development, while Rzasa \& Ogryzek (2017) analyze the social aspects of rural development. Many authors use contemporary methodology in order to research the key issues of agriculture and rural development, thus giving different projections (Fagang, 2017; etc.) and pointing to the importance of the application of modern information and communication technologies in the field of agriculture and rural economy development (Hodge et al., 2017). Galinska (2013) examines agricultural policy of the EU (European Union) from the perspective of WTO (World Trade Organization), Volk et al. (2014) analyze agricultural policy and European integration in South East Europe, while Vujičić et al. (2012) study the European integration and rural development policy in the Western Balkans. Bogdanov (2015) looks at the most important issues of rural development and rural policy of the Republic of Serbia in modern conditions. 
Funding is of a paramount importance, since it has a central role in many areas of the economy and society, particularly in agriculture, i.e. rural economy, where it plays a crucial role in development by determining directions and the degree of development (Radović et al., 2018; Njegomir et al., 2017; Jakšić \& Grbić, 2013; Todorović \& Vuksanović, 2012; etc.). The importance of funding the agriculture and rural development is supported by the example of the EU, where huge amounts of money are allocated to these sectors. In this respect, a very complex policy is implemented (Common Agricultural Policy - CAP), while the EU member states can also use the funding provided by the European Agricultural Guarantee Fund (EAGF) and the European Agricultural Fund for Rural Development (EAFRD).

\section{Key characteristics of agriculture and rural areas of the Republic of Serbia, relevant from the funding perspective}

In addition to very favorable natural conditions for agricultural development in the Republic of Serbia, agriculture is also considered of strategic importance for the country; however, this sector is underdeveloped, mainly due to the lack of funding, obsolete techniques and technologies, insufficient institutional support, low labor productivity, exports of the primary products or less-sophisticated intermediate products, small properties, poor organization of producers into cooperatives, poor cooperation with the processing industry and etc.

According to the Census of Agriculture 2012, there are 631,552 agricultural holdings in the Republic of Serbia, while the agricultural land covers the total area of $3,861,477$ ha. The structure of agricultural holdings is a very complex one. It consists of noncommercial and commercial holdings. Family holdings (total no. of holdings: 628,552 ) utilize $82 \%$ of agricultural land, while agricultural enterprises (total no. of holdings: 3000) utilize 18\% of agricultural land. In terms of the ownership structure of the agricultural enterprises, 2,521 holdings are owned by legal entities and 479 by entrepreneurs. The average utilized agricultural area per family holding is 4.5 ha, while the average size of the utilized agricultural area in terms of holdings owned by legal entities is 210 ha. Small farms (up to 2 ha) have the largest share in the total number of agricultural holdings (about 48\%). Farms which have less than 5 ha, constitute as much as $77 \%$ agricultural holdings, while the largest farms, whose size exceed 50 ha, make less than $1 \%$ of agricultural holdings. The largest number of small farms uses extensive agriculture. The number of registered farms is continuously increasing. A total number of tractors used by the agricultural holdings is 597,816, of which $95 \%$ of tractors have been used for more than 10 years. According to data for 2012, mineral fertilizers were used by about 78\% of holdings and applied on 2,298,574 ha of land. Plant protection products were used by about $72 \%$ of holdings and applied on the total area of $2,107,311$ ha (MAFWE, 2017).

Based on the data for 2016, in terms of the total agricultural land utilized, arable land and vegetable gardens have a share of $75.5 \%$, orchards $4.8 \%$, vineyards $0.6 \%$, meadows $10.0 \%$ and pastures $9.0 \%$. In terms of the structure of the arable land, crops are grown 
on $67.9 \%$ of land (mostly maize and wheat), industrial crops on $15.7 \%$, vegetables on $2.6 \%$, and forage crops on $9.1 \%$ of arable land. Among different kinds of fruit grown in Serbia, plums take the largest share. Considering the total value of agricultural production, plant production takes a share of $66.6 \%$ and livestock production $33.4 \%$. It should be noted that $77 \%$ of holdings are involved in livestock production, however, the majority of farms generally raise a small number of animals (SYRS, 2017). Despite the fact that the animal husbandry sector is insufficiently developed, there are possibilities and opportunities for its development due to the favorable conditions for the production of animal feed and etc.

Rural areas of the Republic of Serbia, in accordance with the OECD definition, occupy about $75 \%$ of the territory and about $50 \%$ of the inhabitants live in these areas. The average population density in rural areas is much lower than in urban ones. The economic structure of rural areas is largely non-diversified, highly dependent on the exploitation of natural resources and the primary sector, mainly agriculture. Based on the data published in the Census of Agriculture, $12 \%$ of agricultural holdings are involved in other profitable activities, most of which include dairy products, while the importance of the tertiary sector is generally small. The major part of the rural labor force (about 45\%) works in agriculture. Additionally, rural labor is employed, though in considerably smaller number, in the manufacturing industry (around 16\%), trade (about $10 \%$ ), construction (about 6\%), transport (4\%) and etc. However, the average net wages earned in the agricultural sector are significantly lower than in other abovementioned sectors (MAFWE, 2017).

One of the most significant demographic characteristics of the rural areas of the Republic of Serbia is the unfavorable age structure of the population. One in every five people who live in rural areas is aged 65 years or older. The average age of the owners of family farms is 59 years of age. Educational characteristics of the rural population are less favorable compared to urban areas (MAFWE, 2017). The share of specific categories of engaged workforce on farms in the total number of annual work units in agriculture (Census of Agriculture, 2012) is as follows: 44\% of owners of agricultural holdings, $47 \%$ of family members and relatives, $4 \%$ of permanent employees on farms and $5 \%$ of seasonal workers and part-time workers.

Agricultural holdings have poor access to basic infrastructure, i.e., underdeveloped road infrastructure and telecommunications networks, lack of heating and sewage systems, inadequate water and electricity supply, lower quality of housing, insufficient availability of public services in rural areas, especially, public administration, education, health and social services. A particular problem is the limited access to funding, followed by rural poverty issues, social exclusion and etc. Regardless the mentioned issues, agriculture and the rural economy are still seen as the development opportunities of the Republic of Serbia (Table 1). 
Table 1. SWOT analysis of the key characteristics of agriculture and rural areas of the Republic of Serbia, relevant from the funding perspective

\begin{tabular}{|c|c|}
\hline Strengths & Weaknesses \\
\hline $\begin{array}{l}\text { - favorable climate conditions for agriculture } \\
\text { - terrain } \\
\text { - biodiversity } \\
\text { - fertility, physical, chemical and biological } \\
\text { properties of agricultural soil } \\
\text { - long agricultural tradition } \\
\text { - rich cultural and historical heritage of rural areas } \\
\text { - defined policies and strategies of agriculture and } \\
\text { rural areas development } \\
\text { - local initiatives for agricultural and rural } \\
\text { development } \\
\text { - examples of good practice } \\
\text { - energy potential of biomass for renewable } \\
\text { energy production } \\
\text { - natural resources for organic farming and rural } \\
\text { tourism }\end{array}$ & $\begin{array}{l}\text { - small non-commercial agricultural households } \\
\text { - low level of specialization } \\
\text { - outdated machinery, equipment and agricultural } \\
\text { facilities } \\
\text { - reluctance to implement modern management } \\
\text { and marketing practices in agricultural holdings } \\
\text { - unfavorable demographic trends and social } \\
\text { structure } \\
\text { - underdeveloped rural infrastructure } \\
\text { - lack of comprehensive advisory services and } \\
\text { continuous training programmes } \\
\text { - limited skills and experience in terms of the } \\
\text { preparation of projects and their implementation } \\
\text { - insufficient budget funds } \\
\text { - complicated access to loans } \\
\text { - problems related to self-financing in agricultural } \\
\text { sector } \\
\text { - farmers' lack of confidence towards different } \\
\text { types of funding } \\
\text { - weak ties between science and practice } \\
\text { - unsustainable natural resources management }\end{array}$ \\
\hline Opportunities & \\
\hline $\begin{array}{l}\text { - larger budgetary support } \\
\text { - EU IPARD II Programme } \\
\text { - use of international financial assistance } \\
\text { - LEADER approach to rural development } \\
\text { - establishment of the Farm Accountancy } \\
\text { Data Network - FADN } \\
\text { - training programmes in the field of finance } \\
\text { - establishment of a specialized agricultural bank } \\
\text { - favorable bank loans } \\
\text { - securities-based funding } \\
\text { - agricultural insurance schemes } \\
\text { - exports of agricultural products } \\
\text { - promotion of eco-development and energy } \\
\text { efficiency }\end{array}$ & $\begin{array}{l}\text { - high costs of improving agricultural production } \\
\text { and rural economy } \\
\text { - climate change } \\
\text { - price volatility } \\
\text { - migrations, especially of young people } \\
\text { - migration of people, especially young people } \\
\text { - rural poverty } \\
\text { - insufficient cooperation at national and local } \\
\text { levels } \\
\text { - lack of quality financial instruments tailored to } \\
\text { the needs of farmers and agribusinesses } \\
\text { - economic and political constraints of internal } \\
\text { and external character }\end{array}$ \\
\hline
\end{tabular}

Source: based on MAFWE, 2017

\section{Available sources of financing agriculture and rural development in the Republic of Serbia}

Although there are several options in terms of financing the agribusiness and rural development, the financial resources continue to represent one of the greatest limitations to the development of the agri-food sector and rural areas of the Republic of Serbia.

Agricultural budget, as part of the total budget of the Republic of Serbia, was established in 1996; however, the amount of funds that are allocated to this budget still depend on 
the socio-economic conditions, rather than the real needs of agriculture and rural areas for financial support (SARD, 2014). In the period between 1996 and 2015, the average share of agricultural budget in the total state budget was about 4.8\% (Radović, 2015). The share of budget allocations for agriculture in the total budget in the recent period is highly inconsistent (Figure 1).

Figure 1. The share of budget allocation to agriculture in total budget funds, in the period 2008 to 2017

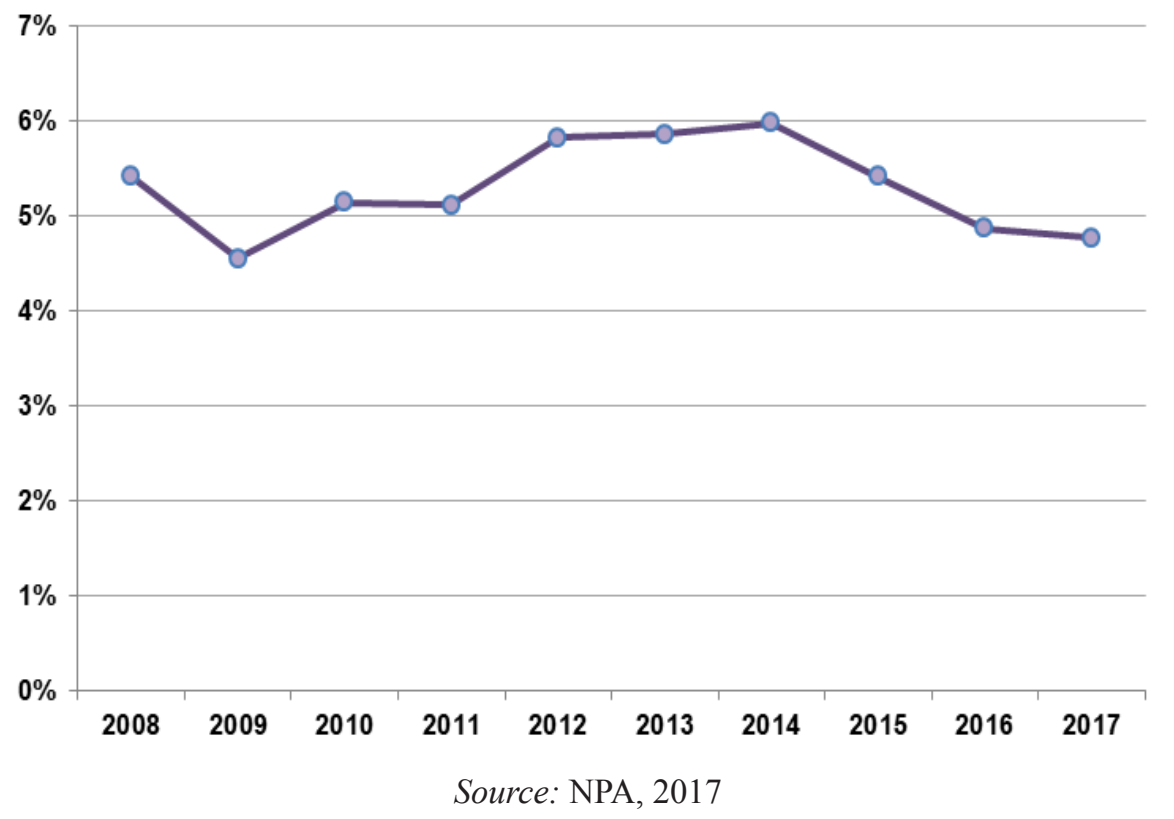

In the period between 2004 and 2012, the measures including the market-price support and direct support to producers accounted for $70 \%-90 \%$ of the total support allocated from the budget; structural and rural development measures constituted a significantly smaller portion of the budget, while the general support measures were least represented (only a few percent of the budget). After 2011, the financial support in the form of market-price support programmes was discontinued. The structure of funds used to subsidize inputs has changed dynamically, with the tendency to concentrate on the fuel and fertilizers price subsidies (SARD, 2014). In 2013, 94.4\% of funds were spent for direct payments, $4 \%$ for rural development and $1.6 \%$ to support the activities of agricultural advisory services and food safety control (MAFWE, 2017). During 2016, the following forms of state financial aid were implemented: compensations, premiums, subsidies for planting the new perennial plantations and improvement of primary agricultural production, investment in agricultural product processing and marketing, conservation of plant and animal genetic resources, and etc. (MAEP, 2017). 
Table 2. Types of subsidies for agriculture and rural development of the Republic of Serbia, 2017

\begin{tabular}{|c|c|}
\hline $\begin{array}{l}\text { Direct } \\
\text { payments }\end{array}$ & $\begin{array}{l}\text { - Milk price support } \\
\text { - Main subsidies for crop production } \\
\text { - Subsidies for livestock production } \\
\text { - Fuel and/or fertilizers price subsidies, as well as subsidies for public warehouses } \\
\text { costs }\end{array}$ \\
\hline $\begin{array}{l}\text { Rural } \\
\text { development } \\
\text { measures }\end{array}$ & $\begin{array}{l}\text { - Subsidies for improving competitiveness } \\
\text { - Subsidies for the conservation and improvement of the environment and natural } \\
\text { resources } \\
\text { - Subsidies for income diversification and improvement of the quality of life in } \\
\text { rural areas } \\
\text { - Subsidies for preparation and implementation of local rural development } \\
\text { strategies } \\
\text { - Subsidies for improving the knowledge creation and transfer systems }\end{array}$ \\
\hline $\begin{array}{l}\text { Specific } \\
\text { subsidies }\end{array}$ & $\begin{array}{l}\text { - Subsidies for implementation of breeding programs, in order to achieve } \\
\text { objectives in livestock production } \\
\text { - Subsidies for the marketing and information systems in agriculture } \\
\text { - Subsidies for production of planting material, certification and clone selection }\end{array}$ \\
\hline Credit sup & rest rate subsidy(subsidizing a part of the interest rate) \\
\hline
\end{tabular}

Source: NPA, 2017

After many years of low spending on subsidies for rural development, a significant increase in the amount of funds allocated for these purposes was recorded in 2017 (Table 2). However, direct payments are still the most important item in terms of the financial support provided for agriculture and rural development (Figure 2).

Figure 2. The average share of individual types of subsidies in total subsidies provided for agriculture and rural development in the period 2013-2017

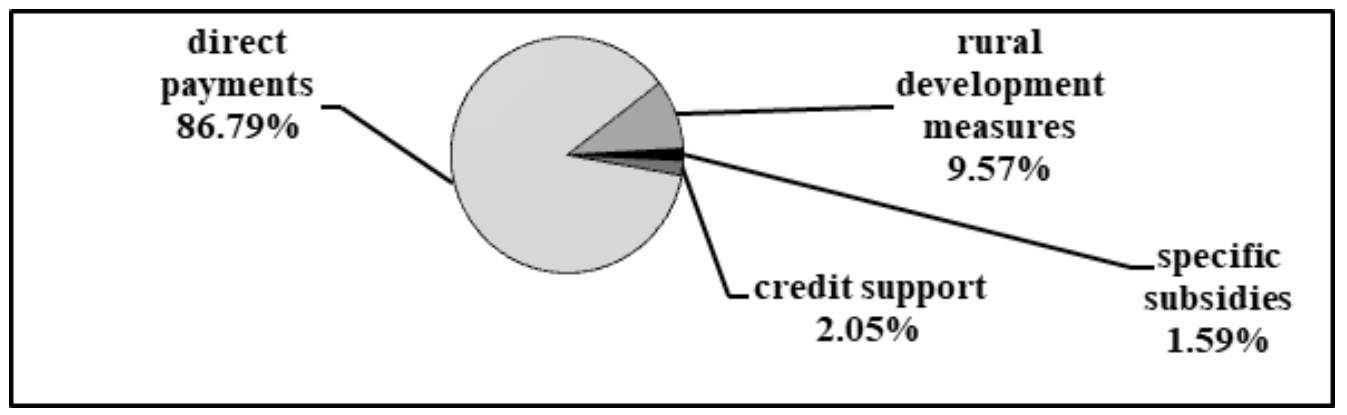

Source: NPA, 2017

Pursuant to the Regulation on the Allocation of Subsidies in Agriculture and Rural Development in 2018 ("Official Gazette of RS", No. 18/18), 17,038,248,000 RSD were earmarked for direct payments, 2.4 billion RSD for the implementation of the rural development measures, 460 million RSD for credit support, 249,130,534 RSD for specific subsidies and 1,434,260,000 RSD for IPARD incentives, of which 358,565,000 RSD are provided from the state budget and 1,075,695,000 RSD are provided from the relevant EU funds. 
Within the Ministry of Agriculture, Forestry and Water Economy of the Republic of Serbia, the Division of Financial Management and the Directorate for Agrarian Payments have been established (Directorate for Agrarian Payments, 2018). At the national level, as well as at the local level (numerous local self-government units), the commitment to rural development and agriculture is evident; however, there is still the lack of budget funds allocated for these purposes.

In terms of the EU support, the following IPA projects aimed at strengthening institutional capacities and preparation for IPARD implementation (Instrument for Pre-Accession Assistance in Rural Development) were completed: IPA 2007 "Capacity building to implement Rural Development policies to EU standards"; IPA 2009 "Technical Assistance to the Directorate for Agrarian Payments"; IPA 2010 "Establishment of the Serbian Farm Accountancy Data Network (FADN)"; IPA 2010 "Equipment and courier service supply and capacity building of Serbian National Referent Laboratories Directorate in food chain"; and etc. The Rulebook on IPARD Programme Incentives and Farmer's Assets ("Official Gazette of RS", No. 84/17) stipulates in detail the general and specific conditions for gaining access to funding, as well as determines other important issues such as qualified expenses and the like. A thorough project preparation is vital for the successful implementation of IPARD. The procedure is very complex and strict monitoring of project activities is implemented. IPARD II programme is very demanding and requires submitting of extensive documentation. Public call for applying for funds provided under the IPARD II for the investments in physical assets on farms - the purchase of a new tractor, was announced in January 2018 (MAFWE, 2018). The Republic of Serbia took part in several CBC programmes, however, projects implemented in agriculture and rural areas are not among the most successful projects funded by the EU.

Farmers in Serbia rarely use bank loans (Table 3). According to them, main issues in terms of the agricultural loans granted by commercial banks, are as follows (Radović, 2014): high interest rates; EUR-indexed loans; unconformity of lending with seasonal nature of the agricultural production; strict requirements for securing loans; high costs of credit insurance; short grace period or no grace period at all; farmers, generally, do not trust banks and etc. On the other hand, due to the high dependence of agriculture on weather conditions, slow capital turnover, and a number of difficulties that borrowers face in their efforts to pay their loan installments on time, agricultural loans do not have a large share in total loans of commercial banks. However, in recent years, a somewhat greater interest for the agricultural loans has been noted. 
Table 3. Agricultural holdings that used subsidies and bank loans, according to Census of Agriculture data

\begin{tabular}{|l|r|}
\hline Total number of agricultural holdings & 631552 \\
\hline No. of agricultural holdings that used subsidies & 179775 \\
\hline -total & 1392 \\
\hline -only the funds provided for rural developments & 168914 \\
\hline -only the funds in form of subsidies & 3259 \\
\hline -subsidized loans only & 6210 \\
\hline -several types of subsidies & 18103 \\
\hline No. of agricultural holdings that took bank loans &
\end{tabular}

Source: Census of Agriculture, 2012

Agricultural equity market is not sufficiently developed in Serbia, in addition, the farmers do not show much interest for this form of financing. Pursuant to the Law on Public Warehouses for Agricultural Products ("Official Gazette of RS", No. 41/09) the Indemnity Fund was formed, a system of public warehouses established and a warehouse receipt (the commodity security which guarantees safe delivery of products stored in the public storage) was introduced (Table 4). Warehouse receipts are considered as a collateral; therefore, commercial banks are allowed to issue loans based on this type of security. However, this form of funding in terms of agriculture and related activities, has not yet become popular.

Table 4. Advantages of the system of public warehouses

\begin{tabular}{|c|c|c|}
\hline $\begin{array}{c}\text { Agricultural } \\
\text { producer }\end{array}$ & Public warehouse & Commercial bank \\
\hline $\begin{array}{l}\text { - } \text { Quality } \\
\text { warehousing } \\
\text { - Safe } \\
\text { warehousing } \\
\text { - Short-term } \\
\text { loans } \\
\text { - Subsidies }\end{array}$ & $\begin{array}{l}\text { - Larger income } \\
\text { - Greater volume of business activities } \\
\text { - Extended business activities } \\
\text { - Sustainability of business activities } \\
\text { - Minimal risk due to Indemnity Fund } \\
\text { guarantee } \\
\text { - Subsidies }\end{array}$ & $\begin{array}{l}\text { - New market niche } \\
\text { - Minimal risk, due to warehouse } \\
\text { receipts which are used as a } \\
\text { collateral, a high level of liquidity of } \\
\text { the deposited goods and the right of } \\
\text { realization of receivables } \\
\text { - Option to use EBRD credit lines }\end{array}$ \\
\hline
\end{tabular}

Source: Indemnity Fund, 2018

Active participation of individual farmers in commodity-stock trade was facilitated by the establishment of the "Agrar Produkt" 1td. in 2003, by the Commodity Exchange in Novi Sad. The main intention behind the establishment of the "Agrar Produkt", was to make this company a link between individual farmers and commodity-exchange market, i.e., the intention was to make this institution the representative of farmers in selling their products through the Commodity Exchange, and in this way practically becoming their broker (CENS, 2018). However, the stock exchange has not attracted the huge interest of local farmers.

Although the financial leasing market has not yet been sufficiently developed in the Republic of Serbia, its role in financing the agriculture and related activities (primarily related to the purchase of agricultural machinery and equipment) is becoming 
increasingly important. The benefits of the financial leasing include: adjustment to the seasonal nature of production; simple and fast procedure of financial leasing contracts realization and the like. Disadvantages of the financial leasing are primarily related to its additional costs, such as the cost of insurance of the subject of leasing (leased asset) and etc. (Radović, 2014).

Agricultural insurance provides financial protection against loss of income, because agriculture is highly vulnerable to the impact of weather conditions. Regardless the fact that the paid insurance premiums are reimbursed by the state, the level of development of the agricultural insurance -measured by the share of insured arable land and farms, the number of insurance policies and the height of insurance premiums, is very low in the Republic of Serbia. This unfavorable situation can be explained by the low insurance culture, standard of living of the rural population and the like (Kočović et al., 2016).

\section{Potential funding sources for agriculture and rural development of the Republic of Serbia}

Persistent lack of funds needed to fund agricultural production and rural development is one of the major problems of the Serbian economy. With this in mind, there is a need to provide more significant financial resources that will be invested in this sector of the country's economy (Vasiljević et al., 2015). There are several available options in order to make this possible.

The public warehouse system, for example, up to 2013, was selves sustainable with 18 licensed public warehouses and estimate from the Indemnity fund is that total amount of loans against warehouses receipts up to the end of 2013 was 50.000.000 Euros, with interest rates $25 \%$ lower compared to regular loans. Accordingly, some recommendations for improvement are: changes of Law on the public warehouses (especially important requirements for all grain warehouses whose providing storing service for third parties to be mandatory licensed as a public warehouses); establishment of the inspection service for public warehouse within the Ministry of Agriculture, Forestry and Water Economy (in practice, it is very important part of the public warehouse system, but this service is not established so far); arrangements with Commodity directorate reserve to recognize public warehouse automatically as authorized Commodity directorate reserve's warehouses; to introduce public warehouse electronic registry, donated in 2009, because by FAO (Kovačević, et al., 2016), electronic database has huge effect on system reliability, interest rates and number of banks involved in the lending against warehouse receipts.

The system of pre-harvest financing is also very interesting. It has been introduced successfully for the first time in Brazil in 1994. The system of pre-harvest financing is introduced as a pilot project for Europe, and it was also introduced in Serbia and Ukraine, with great support of the European Bank for Reconstruction and Development (EBRD). The Law on financing and provision of financing agricultural production (,Official Gazette of RS“, No. 128/14), establishes a new system of financing agriculture in the 
Republic of Serbia, which tend to provide agricultural manufacturers to ensure the favourable financial resources for their production in pre-harvest production process, under very favourable conditions. The Law has been enforced since 1st June 2015. Many believe in the success of this Law. Nevertheless, should not expect that the Law will generate revolutionary success overnight, but it offer a great alternative source of financing for agricultural production and thus promises improvements in the field of financing agriculture in the Republic of Serbia.

It is known that the establishment of modern commodity exchanges and the development of spot and futures markets contributes to building a market-oriented economy, especially the sector of agricultural products. Thereby, the Law on Commodity Market establishes the necessary legal and institutional framework for the development of futures trading, and provides the basis for the introduction of mechanisms to eliminate the biggest risks of doing business. The adoption of the Law on Commodity Market has multiple benefits for the public sector. It allows the organization of the system of support to agriculture through market intervention mechanisms and the expected effects include more efficient management of commodity reserves, as well as improving the agricultural and agribusiness development policy. In Serbia there is currently no adequate legal framework for the development of commodity exchanges, so precise regulation through a comprehensive law on commodity exchanges, as well as a clear definition of law enforcement measures, could contribute to reducing the current risk exposure for business, particularly small and medium-sized enterprises and farmers. In this way, the economy will be able to use derivatives as a risk management instruments, particularly in the field of agricultural products prices (MTTT, 2018).

A viable model of funding agriculture and rural development could be based on significant funding from the agricultural budget. The Strategy of Agriculture and Rural Development of the Republic of Serbia 2014-2024 (SARD), points out that the creation and implementation of a more efficient model of funding the agriculture and rural development is an imperative, since this represents a strategically important issue. Long-term stability of financial resources and equal and unrestricted access to all potential users to funding resources represent the essential prerequisites for the increase in investment activity in the agricultural sector. If there are no specific financial products and services that would provide insurance against production and market risks and motivate economic operators to realize new investments, it is not possible to make any plans relating to the agribusiness development. The establishment of an efficient system of support for agriculture, requires significant institutional adjustments in the direction of establishing and reforming relevant financial institutions and financial instruments. The task of the state is to adapt the legal framework, enable the creation of dialogue and promote innovative solutions in terms of the financial markets and, above all, to ensure efficient and stable budget support (SARD, 2014). The National Programme for Agriculture 2018-2020 (NPA) represents a detailed elaboration of the Strategy for Agriculture and Rural Development of the Republic of Serbia and offers viable solutions in the area of defining and implementing agricultural policy in 
the period 2018-2020. The financial plan included in the NPA consists of the defined groups of measures. NPA, as an operational programme for the implementation of the agricultural policy defines the objectives of the agricultural policy, types of measures and the dynamics of their realization, including the planned funding resources, rules for implementation and indicators for measuring the achievement of objectives. Having in mind the structure of agricultural subsidies of the Common Agricultural Policy of the EU (CAP), other neighboring countries and global tendencies, as well as the structure of national envelope subsidies, it is obvious that the certain changes are necessary. Namely, the most budget funds for agriculture and rural development of the Republic of Serbia are allocated for direct payments. Hence, it is necessary, as soon as possible, more funds gradually reallocate to the other types of subsidies for agriculture and rural development, such as rural development measures, credit support and specific measures. The effects of such changes should be continuously monitored, in order to undertake a timely adjustments if they are needed.

The availability of IPARD funds should strengthen rural communities and agriculture. It is important that the funding provided by IPARD II programme should be focused at (MAFWE, 2017): competitiveness of the agri-food sector; alignment with the veterinary, phytosanitary, environmental and food safety standards of the EU; restructuring and modernization of the sector; development of sustainable resource management practices; strengthening of the LEADER approach and etc. The selection of measures to be included in IPARD II programme must be based on the sectoral analyzes, need assessment and development needs and potentials. Thereby, the experiences of the countries that are users of the IPARD funds are very useful for Serbia. Namely, the successful practice in some new EU member countries was to open paying agency system to banks and other lenders. This system is allowing banks to lower risk since the IPARD approval is lowering the credit risk and banks are able to check status of IPARD approval with paying agency, as well as to establish sort of collateral on IPARD approved project.

The establishment of a specialized agricultural bank is strongly recommended by some experts, while the main activity of this bank should imply the issuance of agricultural loans under favorable conditions, in accordance with the relevant economic principles.

As one of the solutions for addressing insufficient understanding of banks relating to the specificity and the very essence of agricultural activities can be overcome by introducing the grace period, number of different of benefits offered to loyal and regular customers, favorable credit lines, new collaterals etc. Furthermore, it is important to expand the range of risks covered by agricultural insurance lines, that is, to work together with the banks in order to design more favorable loans that would include agricultural production insurance, as a means of an additional security instrument, lower the cost of insurance premiums on a mutually acceptable level and the like (Radulović, 2013).

In order to develop agriculture, it is necessary to more significantly include securities as a means of funding within the concept of providing financial support for agriculture. 
Implementation of futures contracts would enable agricultural operators to better plan their production, provide more secure product placement, protection against market risk, and etc. (Radović, 2015).

The establishment of the FADN system in the Republic of Serbia is of crucial importance, as the implementation of this system would provide a comprehensive overview of the organizational and economic characteristics of the Serbia's agriculture sector and facilitate development of the relevant databases and analytical reports that would be internationally comparable (MAFWE, 2018). Therefore, it would be much easier to establish an adequate funding model.

\section{Conclusions}

The imperatives including development of the rural infrastructure, technological modernization and increased efficiency in terms of agricultural and non-agricultural activities in rural areas of the Republic of Serbia, require much more funding compared to currently available funds. Although both the stakeholders and the interested public are informed about different types of the successful financing models, financial resources are still one of the greatest limitations of the development of the agri-food sector and the rural economy in the Republic of Serbia.

In order to revitalize agriculture and rural areas of the Republic of Serbia, it is necessary to implement more efficient funding modalities. In addition to budgetary support, greater use of EU pre-accession funds and other international funds, as well as the bank loans tailored to the needs of agricultural and rural economy, it is necessary to increase funding through securities and similar financial instruments. Effective funding of agricultural and rural development is possible only within the framework of the fundamental institutional improvements relevant to this area. The role of state is indispensable in this process; however, external support options should also be considered, however these must be in line with the national interests, and above all, the survival and further development of small agricultural holdings.

The main limitation of this research refers to the complexity of the financing issues. The hypothesis set in this paper is confirmed, since it can be concluded that if more quality sources of financing of agricultural and rural development of the Republic of Serbia are provided, together with the adequate institutional support, in accordance with the specific characteristics of the domestic economic environment and the changed international circumstances, it is possible to expect realization of more successful business activities in this sector. 


\section{References}

1. Bogdanov, N. (2015). Rural development and rural policy. Faculty of Agriculture, Belgrade [in Serbian: Богданов, Н. (2015). Рурални развој и рурална политика. Пољопривредни факултет, Београд].

2. CENS - Commodity Exchange in Novi Sad [in Serbian: ПБНС-Продуктна берза Нови Сад], https://www.proberza.co.rs/agrar-produkt/ (March 20, 2018)

3. Census of Agriculture (2012). Census of Agriculture 2012. SORS, Belgrade.

4. Directorate for Agrarian Payments, MAFWE, Republic of Serbia [in Serbian: Управа за аграрна плаћања МПШВ, Република Србија], http://uap.gov.rs/onama/ (March 20, 2018)

5. Fagang, H. (2017). A Study on Rural Development and Trade Economy Based on Expectation-maximization Algorithm. Revista de la Facultad de Ingenieria, 32(14), 589-595.

6. Galinska, A. (2013). EU's agricultural policy in the WTO context. EC-DG AGRI, EU.

7. Hodge, H., Carson, D., Carson, D., Newman, L. \& Garrett, J. (2017). Using Internet technologies in rural communities to access services: The views of older people and service providers. Journal of Rural Studies, 54(VIII), 469-478.

8. Indemnity Fund, Republic of Serbia [in Serbian: Компензациони фонд, Република Србија], http://www.kompenzacionifond.gov.rs/ (March 19, 2018)

9. Jakšić, M. \& Grbić, M. (2013). Reform of the financial system of Serbia-changes and the achieved level of development, Transition effects and prospects of the Serbian economy, University of Kragujevac - Faculty of Economics, Kragujevac, 127-148 [in Serbian: Јакшић, М. \& Грбић, М. (2013). Реформа финансијског система Србије-промене и достигнути ниво развоја, Ефекти транзищије и перспективе привреде Србије, Универзитет у Крагујевцу - Економски факултет, Крагујевац].

10. Kočović, J., Rakonjac-Antić, T. \& Jovović, M. (2016). Possibilities for the development of agriculture insurance in Serbia, State and prospects of agrarian economy and villages in Serbia, University of Belgrade - Faculty of Economics, CID, Belgrade, 205-224 [in Serbian: Кочовић, Ј., Ракоњац-Антић, Т. \& Јововић, М. (2016). Могућности развоја осигурања пољопривреде у Србији, Стање u перспективе агропривреде и села у Србији, Универзитет у Београду Економски факултет, ЦИД, Београд].

11. Kovačević, V., Zakić, V., Milovanović, M., Subić, J. \& Jeločnik, M. (2016). Electronic warehouse receipts registry as a step from paper to electronic warehouse receipts. Economics of Agriculture, 63(3), 801-815.

12. MAEP (2017). Report on the state of agriculture in the Republic of Serbia in 2016 - Book I. Ministry of Agriculture \& Environmental Protection, Republic of Serbia [in Serbian: МПЗЖС (2017). Извештај о стағу у пољопривреди у Републици Србији у 2016.години - књига I. Министарство пољопривреде и заштите животне средине, Република Србија]. 
13. MAFWE (2017). Republic of Serbia IPARD Programme for 2014-2020 ("Official Gazette of RS", No. 84/17). Ministry of Agriculture, Forestry \& Water Economy, Republic of Serbia.

14. MAFWE - Ministry of Agriculture, Forestry \& Water Economy, Republic of Serbia [in Serbian: МПШВ - Министарство пољопривреде, шумарства и водопривреде, Р. Србија], http:/www.minpolj.gov.rs/ (March 2, 2018)

15. Moseley, M. (2003). Rural Development-principles \& practice. SAGE, London.

16. MTTT (2018). Public hearing on the Draft Act on Commodity Market. Ministry of Trade, Tourism and Telecommunications, Republic of Serbia, Belgrade.

17. NPA (2017). National Programme for Agriculture 2018-2020 (“Official Gazette of RS", No. 120/17).

18. Njegomir, V., Tepavac, R. \& Ivanišević, N. (2017). Alternative sources of financing entrepreneurial undertakings in agriculture. Economics of Agriculture, 64(1), 295-306.

19. Radović, G. (2014). Funding of agriculture in the Republic of Serbia. Zaduzbina Andrejevic, Belgrade [in Serbian: Радовић, Г.(2014). Финансирање пољопривреде y Републиичи Србији. Задужбина Андрејевић, Београд].

20. Radović, G. (2015). Financing agriculture in the Republic of Serbia: experiences and opportunities. Economics - Theory and Practice, 8(4), 13-27.

21. Radović, G., Košić, K. \& Demirović, D. (2018). Financing as a key factor of the strategy of sustainable rural tourism development in the Republic of Serbia. Economics of Agriculture, 65(1), 413-426.

22. Radulović, Đ. (2013). Agricultural holding in the process of providing sources of funding, Food for Europe, Economics Institute, Belgrade [Радуловић, Ћ.(2013). Пољопривредно газдинство у процесу обезбеђивања извора финансирања, Храна за Европу, ЕИ, Београд].

23. Rząsa, K. \& Ogryzek, M. (2017). Social aspects of rural development. Journal Baltic Surveying, 7, 42-48.

24. SARD (2014). Strategy of Agriculture and Rural Development of the Republic of Serbia 2014-2024 (“Official Gazette of RS”, No. 85/2014).

25. Sundmaeker, H. (2016). Accelerating System Development for the Food Chain: A Portfolio of over 30 Projects, Aiming at Impact and Growth. International Journal on Food System Dynamics, 7(4), 371-381.

26. SYRS (2017). Statistical Yearbook of the RS 2017. SORS, Belgrade.

27. Todorović, V. \& Vuksanović, E. (2012). The effects of reforms of the regulatory environment on the Serbian banking sector, Institutional changes as a determinant of the economic development of Serbia, University of Kragujevac - Faculty of Economics, Kragujevac, 261-278 [in Serbian: Тодоровић, В. \& Вуксановић, Е. (2012). Ефекти реформских проиеса регулаторног окружења на банкарски сектор Србије, Институционалне промене као детерминанта привредног развоја Србије, Универзитет у Крагујевцу - Економски факултет, Крагујевац]. 
28. Vasiljević, Z., Zakić, V. \& Kovačević, V. (2015). The recent legislature in the Republic of Serbia in area of incentives and financing of agriculture and rural development. Agro-knowledge Journal, 16(1), 33-45.

29. Volk, T., Erjavec, E. \& Mortensen, K. (2014). Agricultural Policy and European Integration in Southeastern Europe. FAO, Budapest.

30. Vujičić, M., Ristić, L. \& Vujičić, S. M. (2012). European integration and rural development policy of the Republic of Serbia and West Balkan countries. Bulgarian Journal of Agricultural Science, 18(4), 519-530. 